\title{
Morphological variations in Cycloclypeus carpenteri: Multiple embryos and multiple equatorial layers
}

\author{
Antonino Briguglio, Shunichi Kinoshita, Erik Wolfgring, and Johann Hohenegger
}

\begin{abstract}
In this work, 17 specimens of Cycloclypeus carpenteri have been analysed by means of microCT scanning. It has been observed that many specimens possess multiple embryos, multiple nepionts and some tests show more than one equatorial layer. The diameter of each proloculus has been measured, and it seems that they are very variable even within the same specimen, therefore questioning the long known theory that schizonts have smaller proloculi than gamonts and also questioning the fact that proloculi in the same species should all have comparable size. Whenever the nepionts are positioned on different planes, thus creating an angle between them, this angle has a significant correlation to the angle connecting different equatorial layers. T-shaped connections are located at the junction between two equatorial layers; these junctions are made by a chamberlet, which possesses an unusually higher number of apertures, resembling the chamberlet structure of the genus Spiroclypeus.
\end{abstract}

Antonino Briguglio. Faculty of Science, Universiti Brunei Darussalam, Jalan Tungku Link, Gadong BE1410, Brunei Darussalam, antonino.briguglio@ubd.edu.bn;

Shunichi Kinoshita. Department of Palaeontology, University of Vienna, Geocenter, Althanstrasse 14, A1090 Vienna, Austria. shunichi.kinoshita@univie.ac.at Johann Hohenegger. Department of Palaeontology, University of Vienna, Geocenter, Althanstrasse 14, A1090 Vienna, Austria. johann.hohenegger@univie.ac.at

Erik Wolfgring. Department of Geodynamics and Sedimentology, University of Vienna, Geocenter, Althanstrasse 14, A-1090 Vienna, Austria. erik.wolfgring@univie.ac.at

Keywords: larger benthic foraminifera; 3D model; micro CT; tomography; teratology; growth pattern

Submission: 9 April 2015 Acceptance: 6 December 2015

\section{INTRODUCTION}

Larger Benthic Foraminifera (LBF) are known to be among the largest and most diverse marine protists that have existed on earth (e.g., Hohenegger, 2011). They build a test whose shapes and structures have been studied for decades and a number of results are now considered as basic knowledge to approach this group of protists (e.g., Hottinger, 2000). Extended biometric studies on some relevant parameters have to be conducted either on the external surface or along oriented sections and are crucial for biostratigraphy, palae-

Briguglio, Antonino, Kinoshita, Shunichi, Wolfgring, Erik, and Hohenegger, Johann. 2016. Morphological variations in Cycloclypeus carpenteri: Multiple embryos and multiple equatorial layers. Palaeontologia Electronica 19.1.3A: 1-22

palaeo-electronica.org/content/2016/1404-morphology-of-c-carpenteri 
oecology and evolution (e.g., BouDagher-Fadel, 2008).

The shape of LBF test is largely the expression of their mechanical support system, which can be explained in terms of functionality, building material and construction plan (Hallock, 2000; Hohenegger, 2011) based on the three aspects 'function', 'phylogenetic inheritance' and 'bauplan' (Seilacher, 1970). These protists are also specialized in photosynthetic algal symbiosis, which is favourable in low nutrient environments but limits the habitat of these organisms to the photic zone of tropic and warm temperate oligotrophic seas. Therefore, LBF modify their test's shape according to their symbionts' requirements and to the energetic scenario they live. The deeper and/or quieter the environment becomes, the flatter are the shapes of LBF possessing hyaline walls (e.g., Hohenegger, 2004; Briguglio and Hohenegger, 2009). Flat shapes, hyaline walls and weak fixation possibilities (e.g., Planostegina, Cycloclypeus) allow the protists to house a large number of symbionts just beneath the test walls, which are needed in case of low light availability as in deeper water and are thus dependent on low hydrodynamics (e.g., Yordanova and Hohenegger, 2007; Briguglio and Hohenegger, 2011). Rounded tests with high density are perfectly adapted to the shallowest waters where their weight and shape help to resist transport. Some species concentrate their ectoplasm at the end of calcified spines to attach themselves to the substrate hindering detachment by the strongest currents (calcarinids) (e.g., Hohenegger, 2004). Flat shapes might also be functional in shallowest environment if coupled with robust structures and possibilities for fixing to the substrate through multiple and complex apertures (e.g., Sorites or Marginopora in Song et al., 1994).

The internal structure of LBF is also a complex architecture of perfect geometries created by a combination of different morphological characters (e.g., Hohenegger, 2011; Benedetti, 2014); archimedean or logarithmic spirals are very common in most spirally shaped LBF and allow protoplasm to easily move within the test, vein-like canal system can be observed into the septa and along the spiral chord or in some other species where a complex stolons' system is created. Changes in the internal structures of LBF have been successfully correlated to time, and most of the shallow water biozones are now calibrated using biometry on selected parameters in LBF (e.g., Less, 1987; Serra-Kiel et al., 1998; Egger et al., 2013).
To observe and measure biometric parameters in tests of LBF, the most common and convenient way is to either prepare oriented sections along determined section of the tests or by splitting the specimen. Since most of the LBF possess planispirally coiled tests and are symmetric along their equatorial plane, this procedure allows us to expose the most important characters of their structures and allows to idealize their three-dimensional structure, which is always lost due to the sectioning process.

A few years ago computed tomography (CT) became a quite common methodology in science, and it is often used in foraminifera to visualize and investigate their internal structure (e.g., Benedetti and Briguglio, 2012; Hohenegger and Briguglio, 2012, 2014; Briguglio and Hohenegger, 2014) or for the visualization of those objects possessing high density differences between the observed characters (e.g., Kedzierski et al., 2015). For LBF, $C T$ investigation perfectly fulfils the requirements for an accurate biometrical analysis avoiding destruction of the specimens and permitting the simultaneous visualization of both equatorial and axial virtual sections (e.g., Briguglio et al., 2013) (Figure 1.1).

A detailed observation of the entire internal structure of an LBF is very important to investigate those specimens affected by teratologies (Ferrandez-Cañadell et al., 2014), complex sub-surface structures (Renema and Cotton, 2015) or to quantify complex characters such as dissolution (Johnstone et al., 2011), shell density (Prazeres et al., 2015) or chamber volume (Briguglio et al., 2011).

Specimen sectioning is useless in those cases where the shapes are irregular because either the complete geometry cannot be fully visualized or because it might not be present along the cutting plane.

In this study, a number of scans are presented revealing some very complex geometries on the surface and the internal structure of several specimens of Cycloclypeus carpenteri Brady, 1881, which have rarely been noticed and never properly described. An attempt to discuss their occurrence in terms of cell physiology and environment is also given.

Some of the observed morphological deviations will also shed some light on a number of aspects like environmental stress response, physiology and reproduction strategies. 

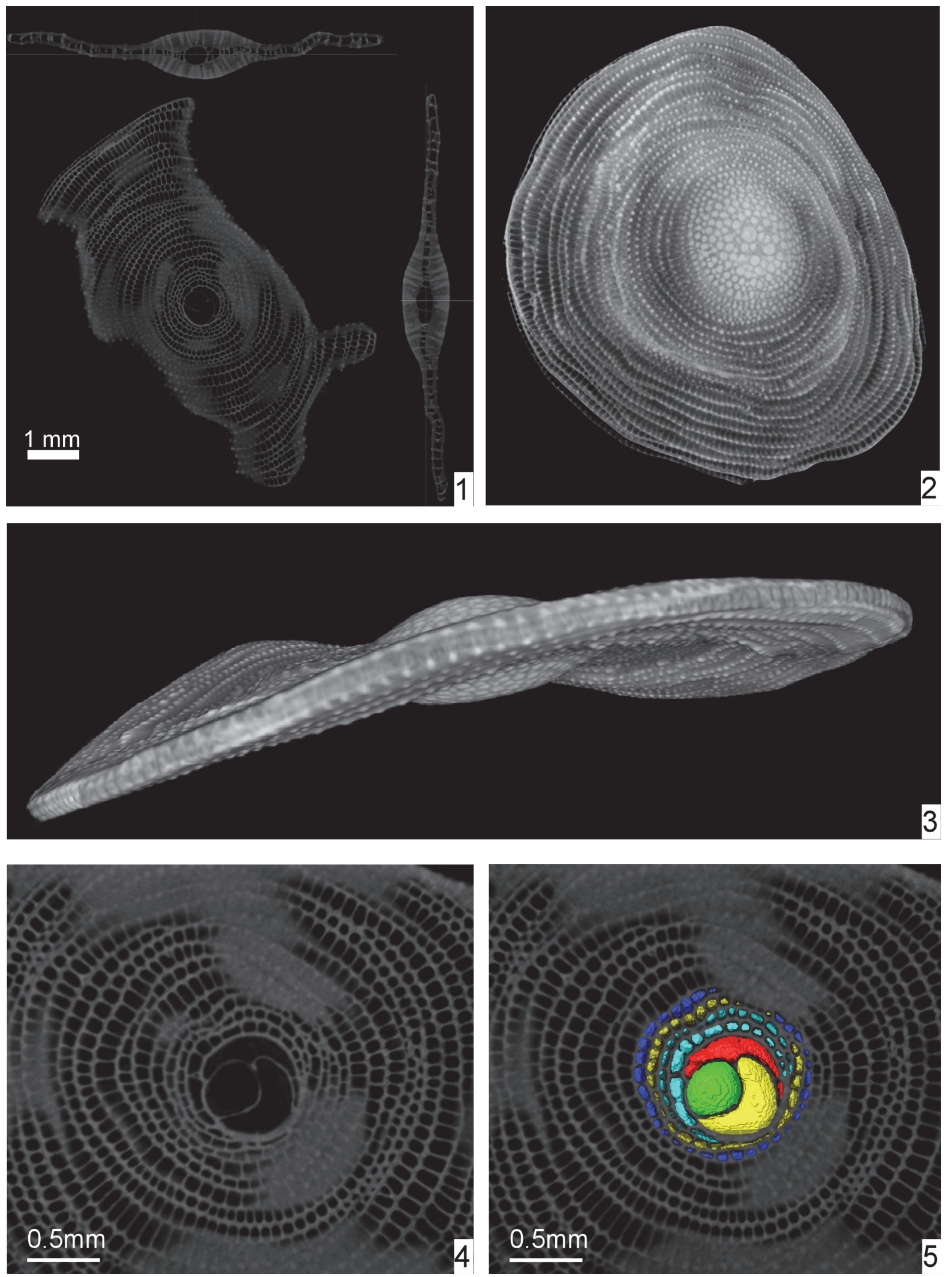

FIGURE 1. Specimen A1: 1) equatorial and axial sections of one specimen.; 2) equatorial view of the test; 3 ) lateral view of the test; 4) close-up to the nepiont and the first chambers in equatorial section; 5) segmentation of the entire nepiont. For more information, refer to text. 


\section{MATERIAL AND METHODS}

The species investigated in this study is Cycloclypeus carpenteri, a very large and flat foraminifer with hyaline tests. This species is well adapted to live in deeper parts of the photic zone (Hohenegger et al., 2000). It has a large, circular and centrally umbonate test narrowed at the periphery (Loeblich and Tappan, 1988) (Figure 1.23; Appendix 1). The microspheric tests can be very large, up to $13 \mathrm{~cm}$, while the megalospheric ones are rarely larger than $1.5 \mathrm{~cm}$. These, (i.e., gamonts and schizonts) are characterized by a rather complex internal structure, which is the main focus of this study.

The internal arrangement of chambers is characterized by a single equatorial layer displaying an annular growth. At the centre of the equatorial layer, the nepiont if visible and represents the initial stage of growth of the foraminifer. It is clearly visible on the equatorial section (Figure 1.4-5) of the test, and it is composed of the proloculus or protoconch (green in Figure 1.5), the deuteroloculus or deuteroconch (yellow in Figure 1.5), one reniform chamber (also known as ana-nepionic chamber) (red in Figure 1.5) and several heterosteginid chambers (two in this case, light blue in Figure 1.5) (also known as nepionic chambers). After the nepiont, the rest of the test is composed by annular chambers (from the dark yellow onward in Figure 1.5) (also known as neanic chambers). All annular chambers are divided into small rectangular compartments, i.e., chamberlets (O'Herne, 1972). Subsequent chamberlets are connected via a complex stolon system, which is smaller than the resolution of the present scan and therefore is not visible here. A three-dimenional (3D) representation of the internal structures as well as the canal system of Cycloclypeus is reported in Renema (2015, figure 2).

In this genus, the canal system, reduced in comparison to other nummulitids, is coupled with a very complex Y-shaped stolon system, which lies in the median plane and connects chambers of subsequent annuli (Hottinger, 1977, figure 7G).

This genus has no lateral chambers or chamberlets (main difference between this genus and the orthophragminids) but its surface is characterized by a relatively thick multilamellar wall, which hampers the view of the equatorial layer and of the juvenarium from the outside.

For this study 17 specimens have been used, and they are numbered from A1 to A18; specimens A15 is not included in this study as the quality of the scan does not allow precise measurements.
All specimens used have been collected at a water depth of $50 \mathrm{~m}$ offshore from the island Ishigaki (Japan) living at the time of collection. They all have been washed with fresh water, dried at room temperature and preserved in plastic containers.

All specimens have been scanned using a high energy MicroCT Skyscan1173 available at the Department of Palaeontology, University of Vienna. Each specimen has been segmented using Amira 5.4.3 VSG. More information on the scanning procedure used here can be found in Briguglio et al. (2014). The samples are stored in the Earth Science collections at the Department of Palaeontology, University of Vienna.

\section{RESULTS}

The presence of more than one proloculus has been observed in eight specimens out of 18 (Figures 2, 3). Such characteristic can only be observed by sectioning the test as it is difficult to impossible to detect it from the external shape of the foraminifer. In few cases, additional proloculi might be located above or below the equatorial layer and therefore are difficult to be detected by the traditional method of sectioning; in such cases only oblique sections or CT scans can visualize the presence of additional chambers and their location. In this population, seven individuals out of $17 \mathrm{spec}-$ imens are found with two or three proloculi and their related deuteroloculi. In specimen A18 the presence of at least 16 proloculi has been observed within the test (Figure 3).

The diameter of every single proloculus has been measured in all investigated specimens and according to this measurement it seems that most of the specimens with one single proloculus are characterized by the lowest proloculus diameters while specimens with more than one embryo possess proloculi with the largest diameters (Figure 3.1). The same analysis done on specimen A18 shows that their diameters vary from 315 to 551 micrometers (Figure 3.2).

For each proloculus in the test, there is always a deuteroloculus connected to it. The differences in proloculus diameter could be compensated by deuteroloculus size, but in the specimens presented in this study the deuteroloculi of multiple embryo individuals are almost always squeezed to each other, and their general shape results are compressed and irregular. Therefore, no measurements on the deuteroloculi have been made.

A further observation is that in some cases the theoretical planes of nepionts where the foramina of the first three chambers lie are placed at differ- 


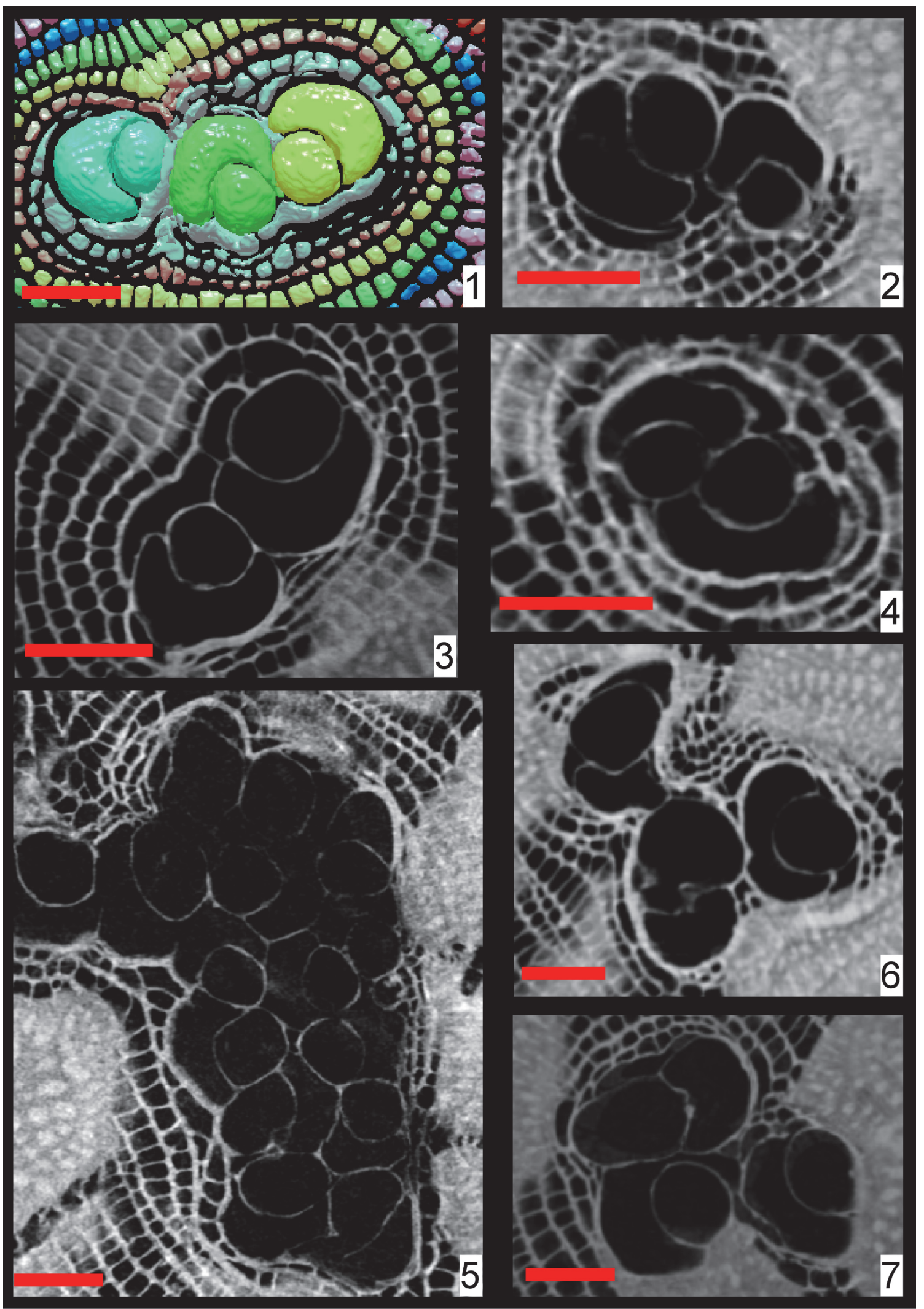

FIGURE 2. Segmentation and equatorial sections of specimens possessing multiple nepionts: 1) specimen A2; 2) specimen A3; 3) specimen A17; 4) specimen A10; 5) specimen A18; 6) specimen A5; 7) specimen A6. Scale bar equals $0.5 \mathrm{~mm}$. 

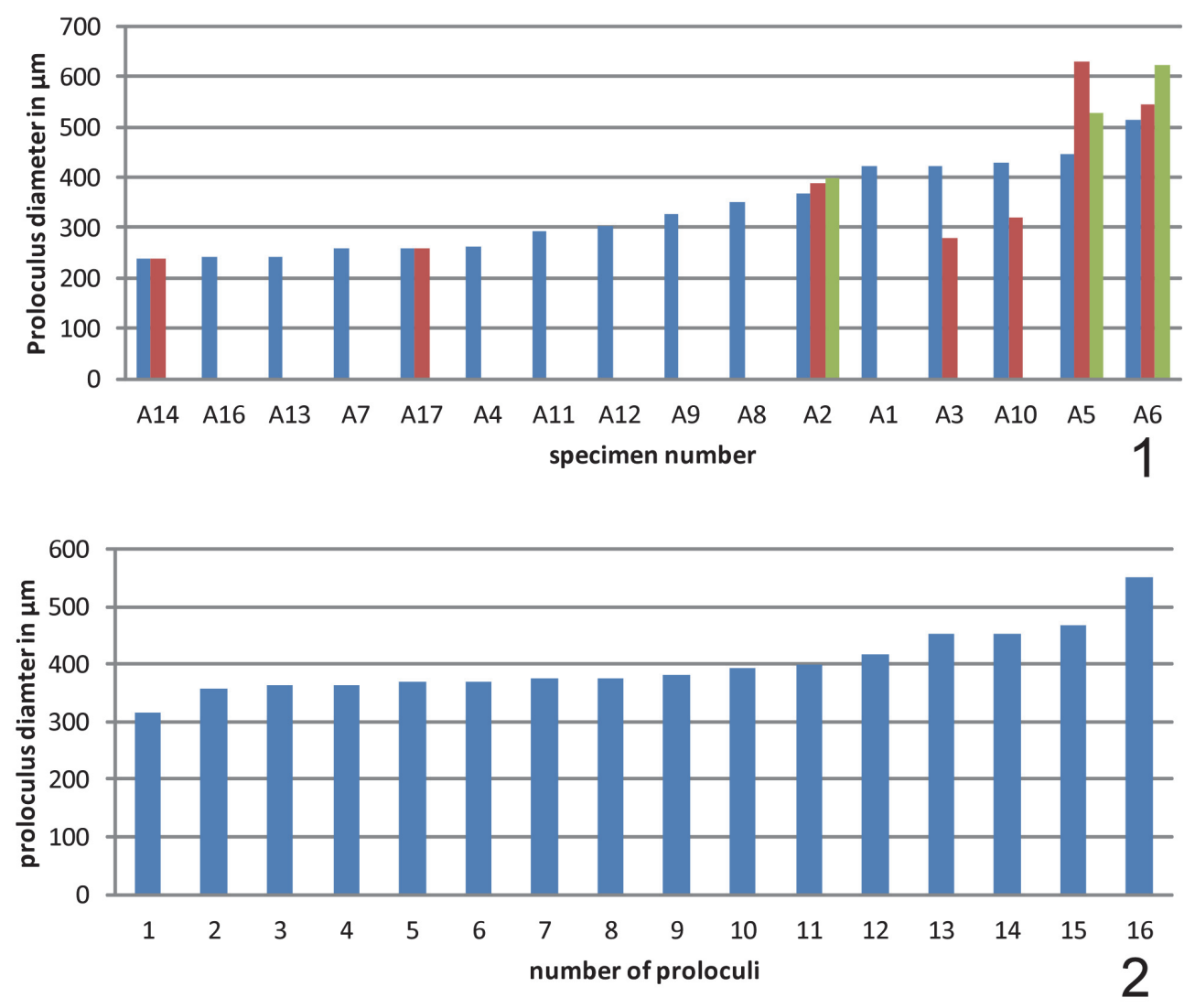

FIGURE 3. Proloculus diameters. 1) proloculus diameter for all individuals in the presented population, except for A18. Multiple bars indicate the presence of several proloculi. 2) diameters of all proloculi identified within the specimen A18.

ent angles to each other. This apparently hampers the construction of flat-shaped tests whilst it favours the creation of additional equatorial layers (Figure 4 and Appendix 2).

In all specimens possessing more than one equatorial layer, chambers of one layer are always connected to those of the other layer and that it is always possible to follow the same chamber throughout all equatorial layers (Figures 4.2-3, 5). These connections, although not visible here because of the low scan resolution, could be possible by additional apertures that shall be positioned at the roof of the connecting chamberlet, thus creating T-shaped connections. Such chamberlets should therefore be characterized by three apertures: two of them are connecting it to the previous and further whorls and the third one is connecting it to the additional equatorial layer. In Cycloclypeus, chamberlets of the same annulus are not directly connected to each other. This morphology is well known in those LBF possessing lateral chamberlets (e.g., Spiroclypeus, Miogypsina as well as in most orthophragminids) where each chamberlet is connected to the two surrounding whorls plus the lateral chamberlets above and below.

\section{DISCUSSION}

The evidence of multiple embryos has been already reported for many foraminifera and also for Cycloclypeus (Hofker, 1927, 1933; Cole, 1963; Briguglio et al., 2014), but its frequency has never been studied and its causes have never been discussed. In some cases, the constant presence of multiple embryos within a population of foraminifera has been used as a taxonomic character to establish a new genus. For example in lepidocyclinids the new genus Pliolepidina (Pliolepidina tobleri Eames et al., 1962) was erected but immediately amended by Cole (1963) as a Lepidocyclina.

First attempts to discuss such multiple embryos can be found in Hofker (1927), where some specimens with more than one embryonic apparatus are described and some measurements 

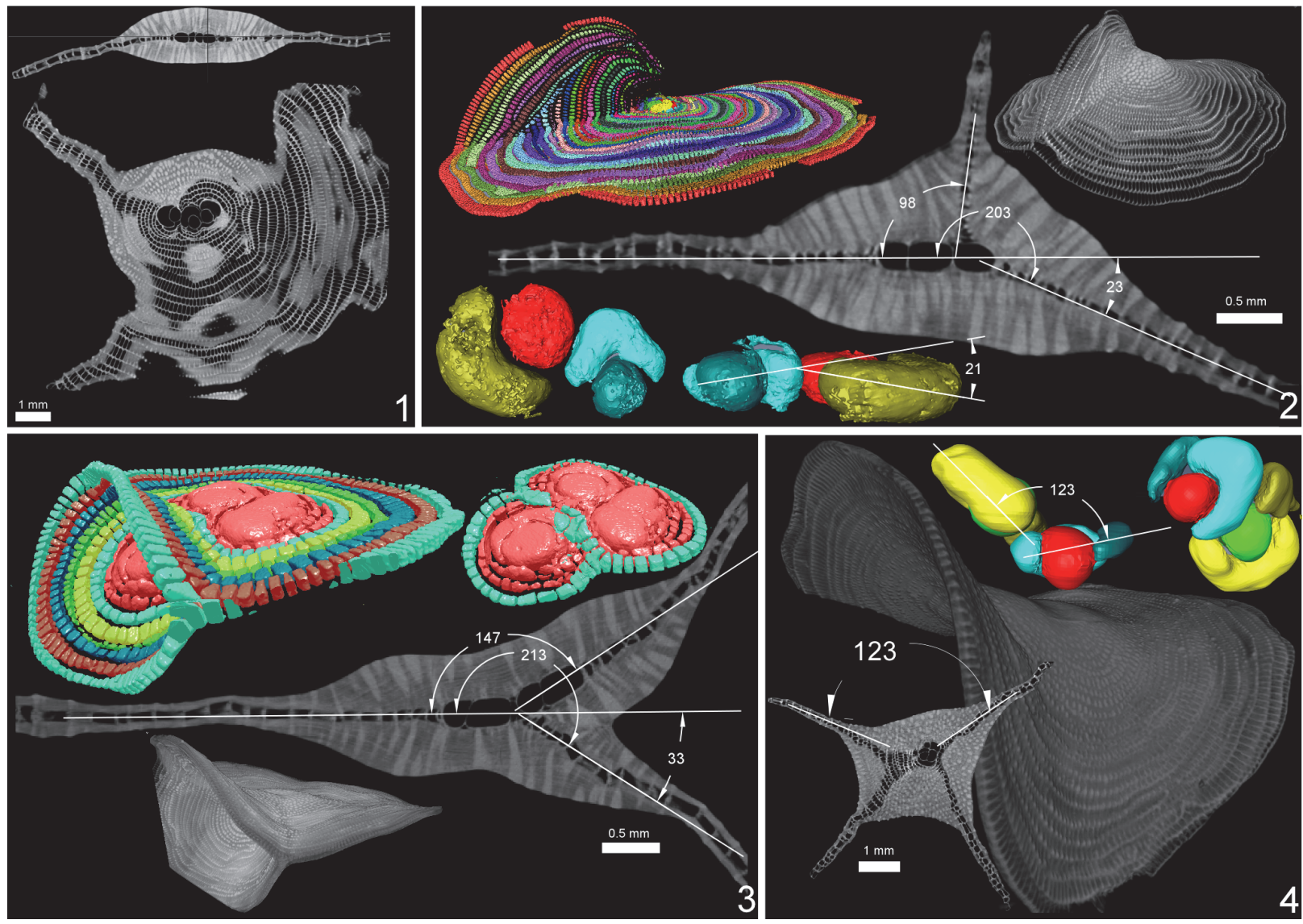

FIGURE 4. Relative position of embryos and secondary equatorial layers: 1) Specimen A2; 2) specimen A3; 3) specimen A6; 4) specimen A14.

are made. Hofker observed that specimens with more nepionts are generally larger than specimens with just a single nepiont and that the deuteroconchs, in multiple nepionts tests, face the periphery of the shell. In the dataset here presented, while most deuteroconchs seem to face the periphery, a relationship between the number of nepionts and size of the test cannot be confirmed. However, in one of his later works, Hofker (1933) could not confirm this relation from several samples collected in the Malay Archipelago. Hofker (1933) also confirms the presence of multiple equatorial layers (named secondary outgrowths).

One of the causes leading to the formation of tests possessing more than one proloculus, can presumably be related to the reproductive cycle of Cycloclypeus. Only asexual reproductions have been observed in the laboratory and have been carefully described after microscopic investigation (Krüger et al., 1996). In these studies, it has been reported that the number of offspring in Cycloclypeus might reach almost 2500 individuals that are released from the mother's test into the surround- ing environment only when they have successfully built their second chamber, the deuteroloculus. The release of the residual protoplasm of the mother cell partly contributes to the dispersal of the offspring. However, the space occupied by such offspring is very large, and it might happen that not all daughter cells manage to get far enough from other individuals to build their first ana-neanic chamber without any external disturbance. A similar observation has been discussed in Peneroplis by Langer et al. (2009). This fact can be further triggered by the environment (in respect to the hydrodynamic regime) where Cycloclypeus normally lives (between 60 and $100 \mathrm{~m}$ water depth): if the offspring are densely packed and if they are neither sufficiently dispersed by the residual mother cell protoplasm, nor by water movements, the occurrence of multiple embryos might be favoured. Hofker (1927) also hypothesized that young nepionts might fuse after they are released by the parental test if not sufficiently distributed in the surrounding environment. 


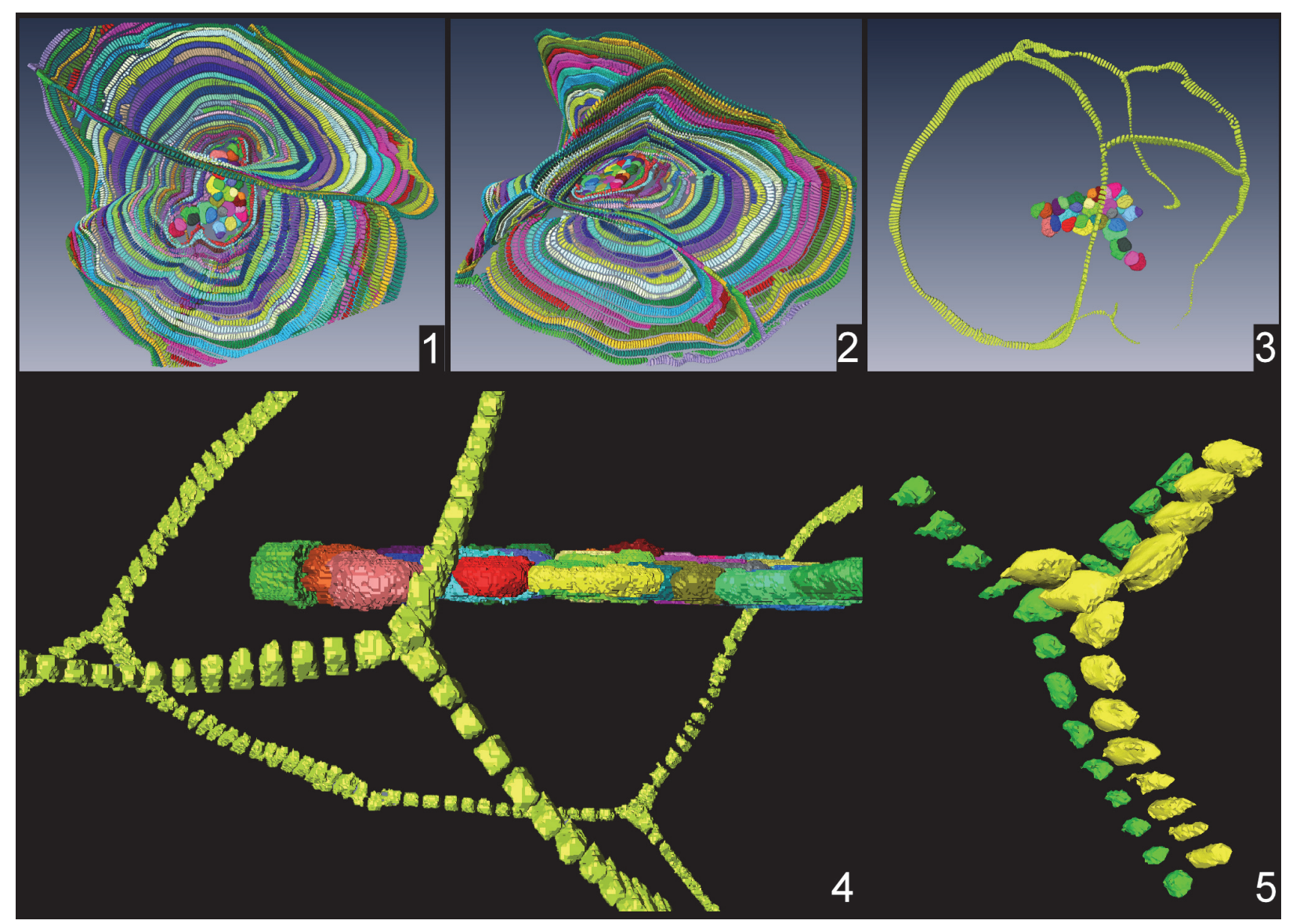

FIGURE 5. Multiple equatorial layers and T-connection in specimen A18.

It seems that tests possessing multiple nepionts do not suffer any sort of physiological problem (i.e., stress), they build one chamber per annulus like their relatives possessing only one nepiont. All physiological functions seem to be normal, the foraminifer cell shows the normal limited growth pattern (Briguglio et al., 2014), building many chambers and will be capable of reproduction. At this stage, it is possible to imagine two different scenarios to explain how two, three or even 16 embryos (each one with his nucleus and eventually nucleoli) can actually coordinate normal growth without interferences. Each chamber building is controlled by one embryo and repressed in the others, similar to complete dominance in diploid organisms, or the entire chamber building system is shared and organized among the nuclei similar to incomplete dominance, semi-dominance or codominance in allele expression of diploid organisms (King et al., 2006). The assumption of acting like co-dominance in diploid organisms is validated by evidence that in some cases, if the geometry of the embryos allows, each embryo can effectively build its own equatorial plane. In one case pre- sented here (Figure 4.3 and Appendix 2), it is possible to observe that the embryos start building their first nepionic chambers separately; then, from neanic chambers they merge together their test and start building one single chamber at the time running through both equatorial planes.

The evidence for multiple equatorial layers in Cycloclypeus has been firstly recorded and described in Carpenter (1856), where he actually defines two main types of splitting based on their angle which occur also in the population here presented. Similar observations were made by Hofker (1933): he concluded that possibly depending on the coiling of the nepionts and on the orientation of the deuteroconchs, the "outgrowths" can be formed or not. However, what neither Carpenter nor Hofker could observe in their specimens-because working only on loose material or on thin sections-was the evidence of perfect connection between equatorial layers: in fact, in these foraminifera possessing more than one equatorial layer, each chamber can be traced along all equatorial layers. For every connection between two different layers, one chamberlet creates a "T-shaped junction"' which 
easily accommodates both directions of the equatorial layers. This is visible also in A18 where 16 proloculi are able to sustain six equatorial layers (Appendices 3, 4, 5). Each chamber can be followed alongside a connection between the two equatorial layers; for every junction there are chamberlets that connect both intersecting layers (Appendices 6, 7). Unfortunately, the scanner used to obtain data for this study did not permit the visualisation of the stolon system.

However, the stolon system for those connecting chamberlets must be of particular interest because it should consist of more apertures to connect the two planes by one single chamberlet. These additional foramina, which have to be included to create a connection between the two equatorial layers, seem to be closely related to the connections visible in species developing lateral chamberlets like Spiroclypeus. Even though no direct correlation seems to be widely accepted between the genus Spiroclypeus and Cycloclypeus, it has been stated several times that both might be considered forms derived from the genus Heterostegina. The genus Spiroclypeus developed lateral chambers at the side of a standard heterosteginid coiling and Cycloclypeus extended the backbending of Heterostegina thus creating its characteristic annuli (Puri, 1957).

It seems that multiple equatorial layers never occur in those specimens with a single nepiont, and it seems that they might occur only if the multiple embryos are placed at different planes. Apparently, in all those specimens possessing multiembryonic apparatus lying on the same plane, no secondary equatorial layer is created (Figure 4.1 and Appendix 8). For those specimens where the embryos lie on different planes, it appears that a correlation exists linking the angle between embryos and the angle between equatorial layers. Specimen A3 (Figure 4.2 and Appendices 9, 10) is characterized by two embryos that differ in size (main proloculus $424 \mu \mathrm{m}$, secondary proloculus $278 \mu \mathrm{m}$ ) and are arranged at an angle of $21^{\circ}$. This value is very similar to the angle that bends the main equatorial layer from a straight plane $\left(23^{\circ}\right)$. The secondary equatorial layers have to grow on a plane, which instead of being flat $\left(180^{\circ}\right)$ is curved at $203^{\circ}\left(180^{\circ}+23^{\circ}\right)$; the angle created by the secondary equatorial layer seems to be located close to the bisector of $201^{\circ}$, at $98^{\circ}$.

Similarly, the specimen A6 (Figure 4.3) is characterized by two proloculi lying on what seems to be the main equatorial plane and one additional proloculus located at an angle of $33^{\circ}$. Similarly to specimen $A 3$, the main equatorial plane is bent at $213^{\circ}(180+33)$ but the additional plane, instead of being located at $106^{\circ}$ as the bisector, is located at a higher value: $147^{\circ}$. Surprisingly, $147^{\circ}$ is exactly two thirds of $213^{\circ}$, pointing to the possibility that those two proloculi lying on the main plane are actually twice as strong as the single nepiont on the additional place therefore creating interesting symmetry.

Specimen A14 (Figure 4.4) is characterized by an external saddle shape; its internal structure is characterized by two proloculi, which are displaced one beneath the other and are inclined at $123^{\circ}$; the angle between the two saddle planes is exactly $123^{\circ}$. It is hard to explain why a secondary equatorial plane is not built and yet there are two nepionts, both lying on two different planes. More data may be needed on saddle shape tests; however, saddle shapes can be explained as they are the result of the junction of two layers which are mutually bended. In this case the two equatorial layers are merged into one and are bent at exactly the same angle as the nepionts.

As stated earlier, specimen A18 is characterized by several equatorial planes, all of them perfectly connected. All observed proloculi seem to lie on the same plane, thus the creation of multiple equatorial planes cannot be fully explained by the above angle model. However, it can also be the case that 16 proloculi need a much larger volume to grow and cannot be fulfilled by one single equatorial layer. Furthermore, the specimen has such a complicated geometry that it is very difficult to spot additional proloculi hidden within the structure.

A further observation presented is the proloculus diameter (Figure 3), which might shed some light on the life cycle of LBF. Foraminifer's life cycle was first described by Winter (1907) as "dimorphic" with an alternation of sexual and asexual generations. In his model, the sexual generation produces microspheric diploid agamonts, which in turn lead to megalospheric haploid gamonts by multiple fission (asexual reproduction). Later, the general life-cycle model was modified to include a third generation, the schizont, positioned between the agamont and the gamont generations (e.g., Rhumbler, 1909; Röttger et al., 1990; Lee et al., 1991; Goldstein, 1999). The modification from the dimorphic to the trimorphic life-cycle model is believed to be valid for all larger symbiont-bearing foraminifera (Langer et al., 2009). Gamonts and schizonts are difficult to differentiate as both have megalospheric embryos and possess similar test morphology. The recognition of schizonts is yet 
only possible by observing their reproduction: they should reproduce small gamonts or schizonts. If they reproduce sexually, they must be gamonts. However, during the last decades it has frequently been observed that after measuring the proloculus diameter within a population of megalospheres, two main groups can be observed represented as significant bimodal frequency distributions: the one with smaller proloculi and the other with larger ones. Forms with smaller proloculi have been identified as schizonts (Lietz, 1996). The first study on proloculus size on populations of $C$. carpenteri is by Hokfer (1927) who defined one microspheric form and two megalospheric forms, those characterized by proloculus diameters of $450 \mu \mathrm{m}$ and 150 $\mu \mathrm{m}$ in average. Lietz (1996) also described three forms with very different proloculus size: the agamonts (average proloculus diameter of $60 \mu \mathrm{m}$ ), the gamonts (average proloculus diameter of $450 \mu \mathrm{m}$ ) and the schizonts (average proloculus diameter of $150 \mu \mathrm{m})$.

In the data presented here it is not possible to identify two different groups of proloculus size but there is a quite continuous range of measurements from small $(200 \mu \mathrm{m})$ to very large proloculi $(400$ $\mu \mathrm{m})$, so the identification of schizonts or gamonts by proloculus size is in the material presented here not possible. Today it is unclear if schizonts are diploid or haploid, i.e., meiosis takes place in the agamont leading to haploid schizonts or after several generations of asexually reproduced diploid schizonts in a schizont resulting in gamonts. In the case of diploid schizonts, they possess genetic identity relieving the communication between offspring because of genetic identity, but this must not be an argument for schizonts creating multiple nepionts.

Therefore, if all tests with multiple nepionts are created by diploid schizonts, their proloculus diameter varying around $150 \mu \mathrm{m}$ should be similar and smaller than gamonts varying around $300 \mu \mathrm{m}$. According to the results shown in Figure 3 , it is exactly the opposite: those tests possessing three nepionts have the largest diameters of proloculi (A2, A5 and A6), specimens with two nepionts possess the smallest proloculi (A14 and A17), and there are specimens with one single nepiont characterized by proloculus size ranging from 200 to $400 \mu \mathrm{m}$ (e.g., A16 and A1) thus indicating gamonts according to the division using proloculus size. The 16 proloculi measured on A18 show very large diameters (Figure 3.2) if compared with the investigated population (Figure 3.1) leading to the assumption that most specimens of the investi- gated population have to be regarded as gamonts according to proloculus size and variability. Furthermore, the distribution of Cycloclypeus at lower hydrodynamic conditions compared to the upper reef slope makes asexual reproduction of agamonts creating asexually reproducing schizonts unnecessary, compared to the differing reproduction types between shallow (strong hydrodynamics) and deep living (weak hydrodynamics) Heterostegina depressa, where in the former schizonts and in the latter gamonts are produced (Biekart et al., 1985).

\section{CONCLUSION}

CT investigation on Cycloclypeus carpenteri revealed a number of data, which are impossible to get from oriented sections and external view. In this study three major results are displayed and discussed.

The first main result is that specimens possessing multiple embryos can build many chambers, and their growth is not hampered by the coexistence of the nepionts. The extreme case of a specimen with 16 proloculi is illustrated possessing several equatorial layers each characterized by a large number of chambers.

Furthermore, multiple nepionts can lead to the creation of multi-equatorial layers, which can be banded at specific angles. There is a geometric relation between the angle between nepionts and the angle between equatorial layers.

Finally, the proloculus diameter, which is considered to be significant to discriminate gamonts and schizonts, is extremely variable within a population and within clones of a single specimen, but is significantly larger than the size of proloculi in schizonts. The hypothesis of being gamonts is strengthened by the explanation as acting of the multiple haploid nuclei like genes in diploid to multiploid single cells, where the phenotypic expression of genes related to chamber construction can best be explained by co-dominance of alleles, substituted by genes of the haploid nuclei.

\section{ACKNOWLEDGEMENTS}

This work was developed within the project "Functional Shell Morphology of Larger Benthic Foraminifera" of the Austrian Science Fund (FWF; grant P23459-B17). We thank the Institute of Palaeontology, University of Vienna, for letting us scan all presented specimens and for providing a dedicated working station for analysing the data sets. Two anonymous reviewers are deeply 
acknowledged as their comments greatly improved an earlier version of the manuscript.

\section{REFERENCES}

Benedetti, A. 2014. Spiral growth in Nephrolepidina: evidence of "golden selection". Paleobiology, 40:151161.

Benedetti, A. and Briguglio, A. 2012. Risananeiza crassaparies $\mathrm{n}$. sp. from the Late Chattian of Porto Badisco (southern Apulia). Bollettino della Società Paleontologica Italiana, 51:167-176.

Biekart, J.W., Bor. T., Röttger, R., Drooger, C.W., and Meulenkamp, J.E. 1985. Megalospheric Heterostegina depressa from Hawaii in sediments and laboratory cultures. Palaeontology, Proceedings, B88:1-20.

BouDagher-Fadel, M.K. 2008. Evolution and geological significance of larger benthic foraminifera. Developments in Palaeontology and Stratigraphy, 21:1-548.

Brady, H.B. 1881. Notes on some of the Reticularian Rhizopoda of the "Challenger" Expedition. Part III. Quarterly Journal of Microscopical Science, 21(81):31-71.

Briguglio, A. Metscher, B. and Hohenegger, J. 2011. Growth Rate Biometric Quantification by X-ray Microtomography on Larger Benthic Foraminifera: Threedimensional Measurements push Nummulitids into the Fourth Dimension. Turkish Journal of Earth Science, 20:683-699.

Briguglio, A. and Hohenegger, J. 2009. Nummulitids hydrodynamics: an example using Nummulites globulus Leymerie, 1846. Bollettino della Società Paleontologica Italiana, 48:105-111.

Briguglio, A. and Hohenegger, J. 2011. How to react to shallow water hydrodynamics: the larger benthic foraminifera solution. Marine Micropaleontology, 81:6376.

Briguglio, A. and Hohenegger, J. 2014. Growth oscillation in larger benthic foraminifera. Paleobiology, 40:494-509. doi:10.1666/13051

Briguglio, A., Hohenegger, J., and Less, G. 2013. Paleobiological applications of three-dimensional biometry on larger benthic foraminifera; a new route of discoveries. Journal of Foraminiferal Research, 43:67-82.

Briguglio, A., Wöger, J., Wolfgring, E., and Hohenegger, J. 2014. Changing investigation perspectives: methods and applications of computed tomography on larger benthic foraminifera, p. 55-70. In Kitazato, $\mathrm{H}$. and Bernhard, J. (eds.), Experimental Approaches in Foraminifera: Collection, Maintenance and Experiments. Springer, Environmental Science Series, Japan.

Carpenter, W.B. 1856. Researches on the Foraminifera, part II. On the genera Orbiculina, Alveolina, Cycloclypeus and Heterostegina. Philosophical Transactions of the Royal Society, 146:547-569.

Cole, W.S. 1963. Tertiary larger Foraminifera from Guam. U.S. Geological Survey Professional Papers 403-E, 57p.

Eames, F.E., Banner, F.T., Blow, W.H., and Clarke, W.J. 1962. Morphology, taxonomy, and stratigraphic occurrence of the Lepidocyclininae. Micropaleontology, 8:289-321.

Egger, H., Briguglio, A., Rögl, F., and Darga, R. 2013. The basal Lutetian Transgression on the Tethyan shelf of the European craton (Adelholzen formation, Eastern Alps, Germany). Newsletters of Stratigraphy, 46: 287-301. doi:10.1127/0078-0421/2013/0035

Ferràndez-Cañadell, C., Briguglio, A., Hohenegger, J., and Wöger, J. 2014. Test fusion in adult foraminifera: A review with new observations of an early Eocene Nummulites specimen. Journal of Foraminiferal Research, 44:316-324.

Goldstein, S.T. 1999. Foraminifera: a biological overview, p. 37-55. In Sen Gupta, B.K. (ed.), Modern Foraminifera. Kluwer Academic Publishers, New York.

Hallock, P. 2000. Symbiont-Bearing Foraminifera: Harbingers of global change? Micropaleontology, 46:95104.

Hofker, J. 1927. The Foraminifera of the Siboga Expedition: Tinoporidae, Rotaliidae, Nummulitidae, Amphisteginidae. Brill, Leiden, Netherlands.

Hofker, J. 1933. Foraminifera of the Malay Archipelago. Papers from Dr. Th. Mortensen's Pacific Expedition, 1914-16, Pacific Expedition. Videnskabelige meddelelser fra Dansk Naturhistorisk Forening i København, 93. Leiden, Netherlands.

Hohenegger, J. 2004. Depth coenoclines and environmental considerations of Western Pacific larger foraminifera. Journal of Foraminiferal Research, 34:9-33.

Hohenegger, J. 2011. Large Foraminifera: Greenhouse Constructions and Gardeners in the Oceanic Microcosm. The Kagoshima University Museum, Kagoshima, Japan.

Hohenegger, J. and Briguglio, A. 2012. Axially oriented sections of nummulitids: a tool to interpret larger benthic foraminiferal deposits. Journal of Foraminiferal Research, 42:145-153.

Hohenegger, J. and Briguglio, A. 2014. Methods for estimating growth pattern and lifetime of foraminifera based on chamber volumes, p.29-54. In Kitazato, $\mathrm{H}$. and Bernhard, J. (eds.), Experimental Approaches in Foraminifera: Collection, Maintenance and Experiments. Springer Environmental Science Series Japan

Hohenegger, J., Yordanova, E., and Hatta, A., 2000. Remarks on West Pacific Nummulitidae (Foraminifera). Journal of Foraminiferal Research, 30:3-28.

Hottinger, L. 1977. Les Foraminiferes Operculiniformes. Mémoires du Muséum National d'Histoire Naturelle, $\mathrm{C}, \mathrm{XL}$.

Hottinger, L. 2000. Functional morphology of benthic foraminiferal shells, envelopes of cells beyond measure. Micropaleontology, 46:57-86.

Johnstone, H.J.H., Yu, J., Elderfield, H., and Schulz, M. 2011. Improving temperature estimates derived from $\mathrm{Mg} / \mathrm{Ca}$ of planktonic foraminifera using X-ray computed tomography-based dissolution index, XDX. Paleoceanography, 26(1), PA1215. 
Kędzierski, M., Uchman, A., Sawlowicz, Z., and Briguglio, A. 2015. Fossilized bioelectric wire - the trace fossil Trichichnus. Biogeosciences, 12:1-9. doi: 10.5194/ bg-12-1-2015

King, R.C., Stansfield, W.D., and Mulligan, P.M. 2006. A Dictionary of Genetics, $7^{\text {th }}$ ed. Oxford University Press, Oxford, UK.

Krüger, R., Röttger, R., Lietz, R., and Hohenegger, J. 1996. Biology and reproductive processes of the larger foraminiferan Cycloclypeus carpenteri (Protozoa, Nummulitidae). Archive für Protistenkunde, 147:307-321.

Langer, M., Makled, W.A., Pietsch, S.J., and Weinmann, A. 2009. Asynchronous calcification in juvenile megalospheres: an ontogenetic window into the life cycle and polymorphism of Peneroplis. Journal of Foraminiferal Research, 39:8-14.

Lee, J.J., Faber, W.W., Anderson, O.R., and Pawlowski, J. 1991. Life-cycles of foraminifera, p. 285-334. In Lee, J.J. and Anderson, O.R. (eds.), Biology of Foraminifera. Academic Press, London.

Less, G. 1987. Paleontology and stratigraphy of the European Orthophragminae. Geologica Hungarica, Series Palaeontologica, 51:1-373.

Lietz, R. 1996. Untersuchungen zur Individualentwicklung der Groforaminifere Cycloclypeus carpenteri Carpenter (1856). Unpublished Masters thesis. Institut für Allgemeine Mikrobiologie an der ChristianAlbrechts Universität, Kiel, Germany.

Loeblich, A.R. and Tappan, H. 1988. Foraminiferal Genera and Their Classification. Van Nostrand Reinhold Company, New York.

O'Herne, L. 1972. Secondary chamberlets in Cycloclypeus. Scripta Geologica, 7:1-35.

Prazeres, M., Uthicke, S., and Pandolfi, J.M. 2015. Ocean acidification induces biochemical and morphological changes in the calcification process of large benthic foraminifera. Proceedings of the Royal Society B. 282:20142782. doi:10.1098/ rspb.2014.2782
Puri, H.S. 1957. Reclassification, structure and evolution of the Family Nummulitidae. Journal of the Paleontological Society of India, 2:95-108.

Renema, W. 2015. Spatiotemporal variation in morphological evolution in the Oligocene-Recent larger benthic foraminifera genus Cycloclypeus reveals geographically undersampled speciation. GeoResJ, 5:12-22.

Renema, W. and Cotton, L. 2015. Three dimensional reconstructions of Nummulites tests reveal complex chamber shapes. PeerJ 3:e1072. doi:10.7717/ peerj.1072

Rhumbler, L. 1909. Die foraminiferen (Thalamophoren) der plankton-expedition, 1. Teil, p. 1-331. In Hensen, V. (ed.), Ergebnisse der Plankton-Expedition der Humboldt-Stiftung: Lipsius und Tischer, Kiel, v. 3.

Röttger, R., Krüger, R., and de Rijk, S., 1990. Trimorphism in Foraminifera (Protozoa): verification of an old hypothesis. European Journal of Protistology, 25:226-228.

Seilacher, A. 1970. Arbeitskonzept zur Konstruktionsmorphologie. Lethaia 3:393-396.

Serra-Kiel, J., Hottinger, L., Caus, E., Drobne, K., Ferràndez, C., Jaurhi, A.K., Less, G., Pavlovec, R., Pignatti, J., Samsó, J.M., Schaub, H., Sirel, E., Strougo, A., Tambareau, Y., Tosquella, J., and Zakrevskaya, E. 1998. Larger foraminiferal biostratigraphy of the Tethyan Paleocene and Eocene. Bulletin de la Société Géologique de France, 169:281-299.

Song, Y., Black, R.G., and Lipps, J.H. 1994. Morphological optimization on the largest living foraminifera: implication from finite element analysis. Paleobiology, 20:14-26.

Winter, F.W. 1907. Zur Kenntniss der Thalamophoren, 1. Untersuchungen ueber Peneroplis pertusus (Forska I). Archiv fur Protistenkunde, 10:1-113.

Yordanova, E. and Hohenegger, J. 2007. Studies on settling, traction and entrainment of larger benthic foraminiferal tests: implication for accumulation in shallow marine sediments. Sedimentology, 54:12731306. 


\section{APPENDIX 1.}

External view of the specimen A1. Note the surface ornamentation and the gently wavy profile. This specimen has only one nepiont (see palaeo-electronica.org/content/2016/1404-morphology-of-c-carpenteri).

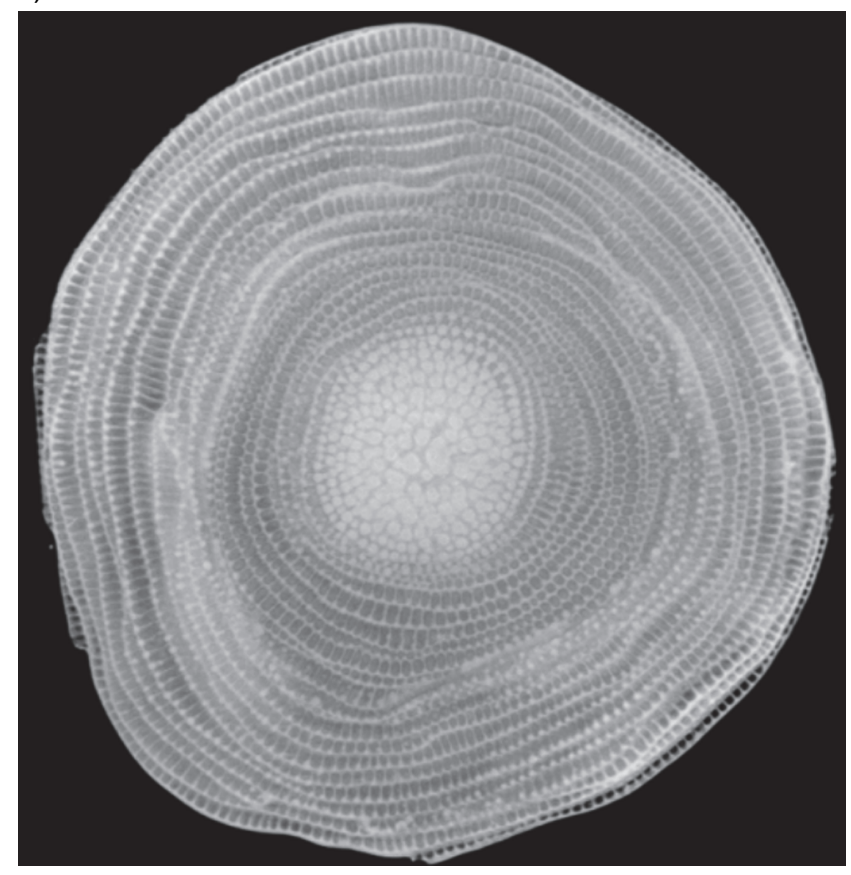




\section{APPENDIX 2.}

CT rendering of the three nepionts and the first chambers of specimen A6. Note that two nepionts are on the same plane whereas the third nepiont is tilted. Each of the three proloculus-deuteroloculus couplets builds its own ana-nepionic chamber; then the first two nepionts share some of their nepionic chambers, while those of the third nepionts are still clearly separated. The fusion of the third nepiont with the other two happens from the first neanic chamber (first in light blue). Note how each neanic chamber runs through both planes thus creating T-shape connections (see palaeo-electronica.org/content/2016/1404-morphology-of-c-carpenteri).

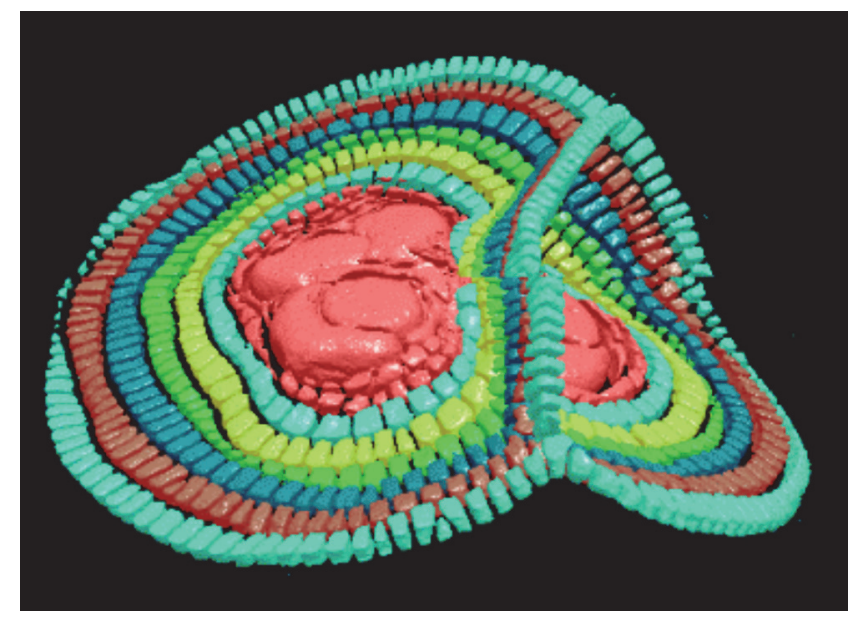




\section{APPENDIX 3.}

Portion of the external surface of specimen A18. Note the multiple equatorial planes all connected each other. Bryozoans, serpulids and other small shells fragments are visible on some surfaces (see palaeo-electronica.org/content/2016/1404-morphology-of-c-carpenteri).

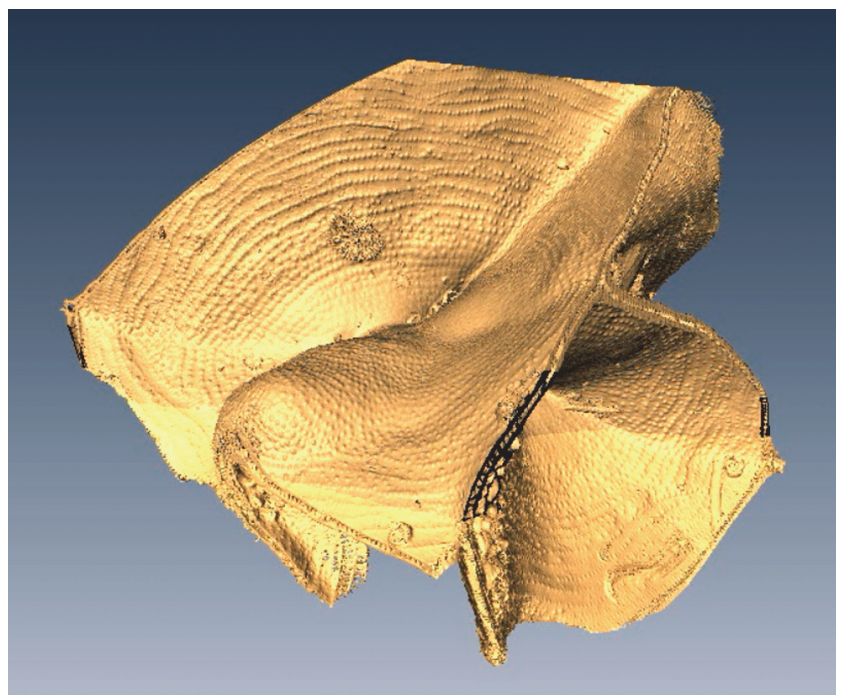




\section{APPENDIX 4.}

CT rendering of all nepionts and all equatorial planes in specimen A18. Note how each chamber runs through all equatorial planes with T-shape connections (see palaeo-electronica.org/content/ 2016/1404-morphology-of-c-carpenteri).

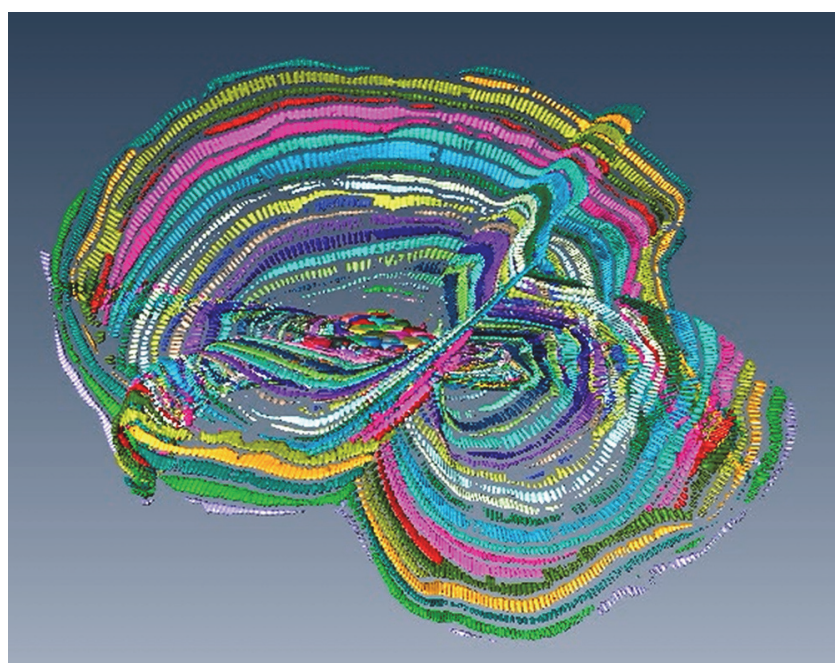




\section{APPENDIX 5.}

CT rendering of all nepionts and all equatorial planes in specimen A18. Note how each chamber runs through all equatorial planes with T-shape connections (see palaeo-electronica.org/content/ 2016/1404-morphology-of-c-carpenteri).

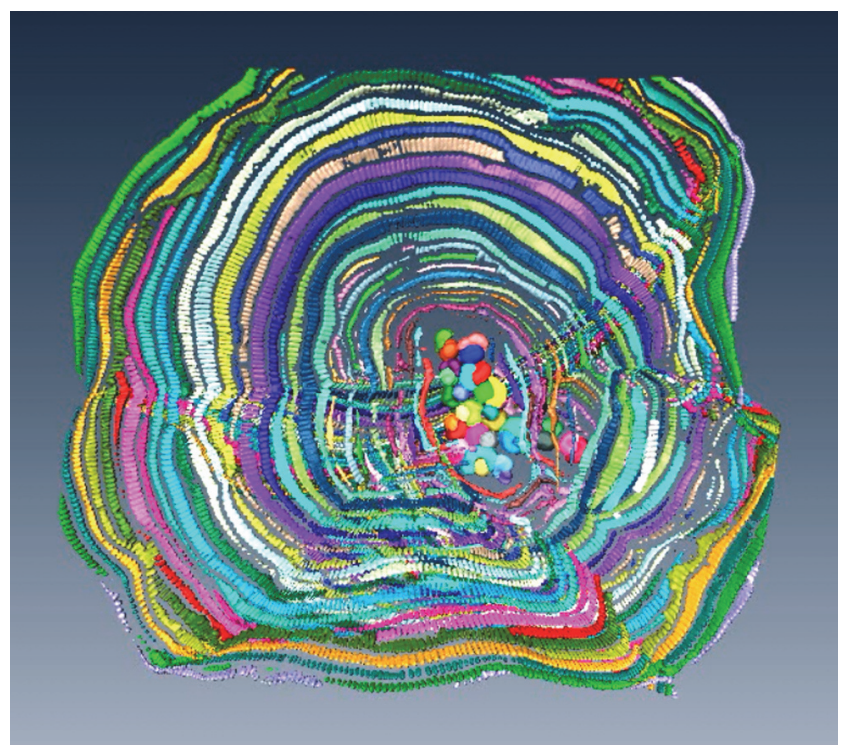




\section{APPENDIX 6.}

Close-up of all nepionts and one chamber running through all equatorial planes in specimen A18. Note the T-shape connections. Due to the resolution of the CT used and the size of the specimen, the smallest chamberlets could not be segmented, here only well visible chamberlets are presented (see palaeo-electronica.org/content/2016/1404-morphology-of-c-carpenteri).

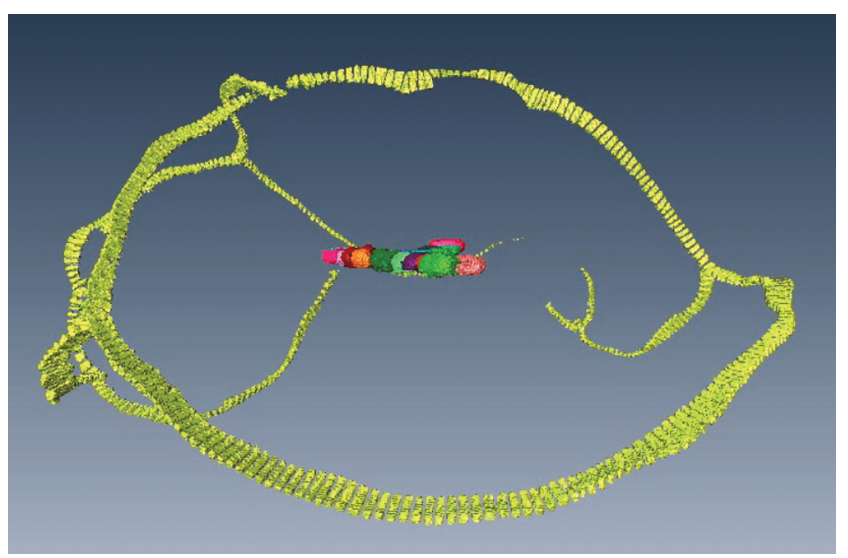




\section{APPENDIX 7.}

Close-up of all nepionts and one chamber running through all equatorial planes in specimen A18. Note the T-shape connections. Due to the resolution of the CT used and the size of the specimen, the smallest chamberlets could not be segmented, here only well visible chamberlets are presented (see palaeo-electronica.org/content/2016/1404-morphology-of-c-carpenteri).

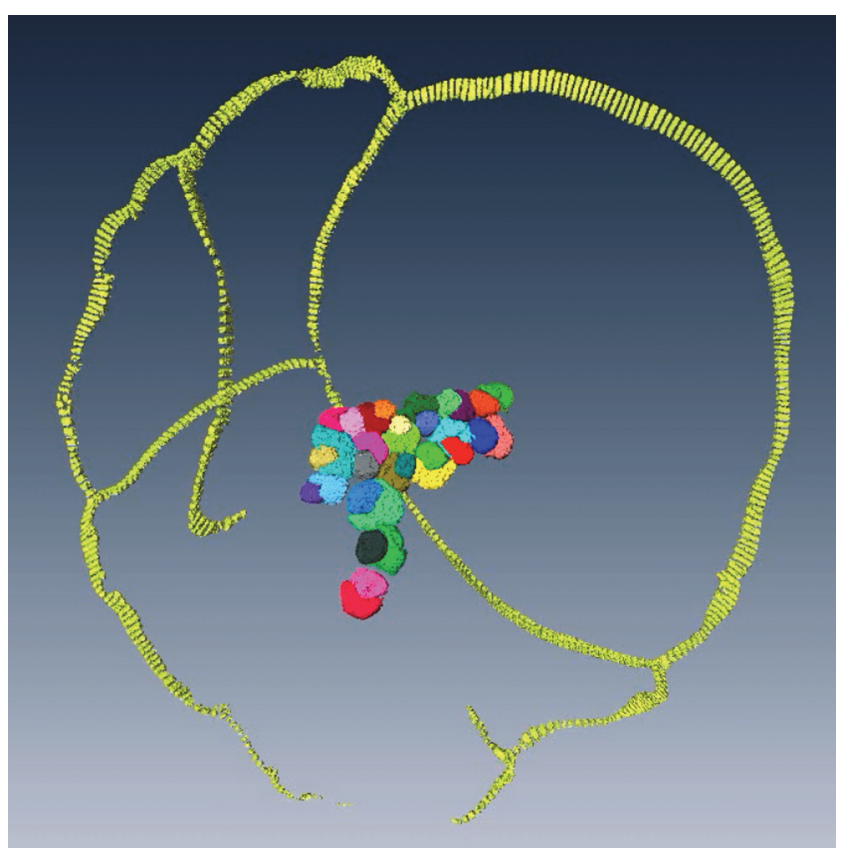




\section{APPENDIX 8.}

$\mathrm{CT}$ rendering of the nepionts and the first chambers of specimen A2. Note that the three nepionts share some nepionic and all neanic chambers. These three nepionts built one equatorial layer only (see palaeo-electronica.org/content/2016/1404-morphology-of-c-carpenteri).

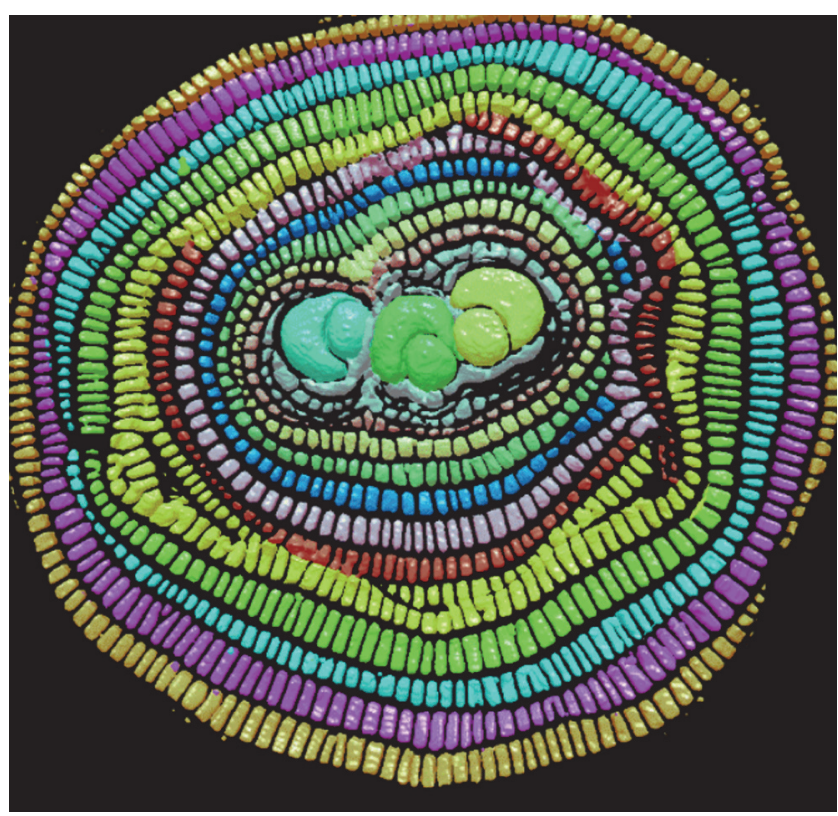




\section{APPENDIX 9.}

External view of specimen A3. Note the two equatorial layer nicely connected by T-shape connections (see palaeo-electronica.org/content/2016/1404-morphology-of-c-carpenteri).

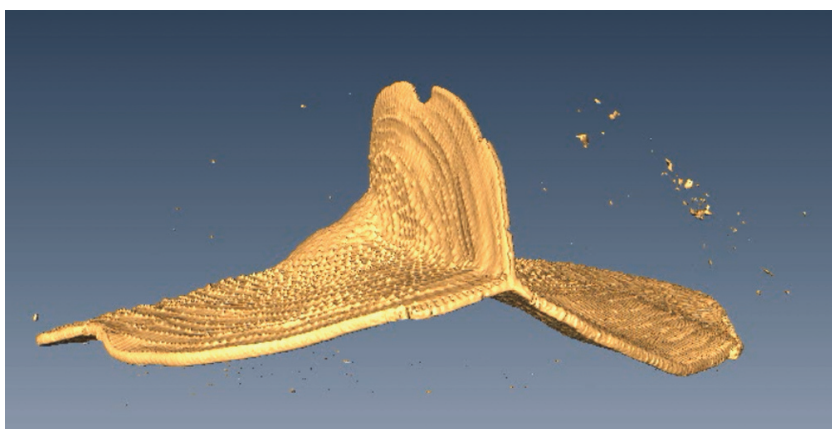




\section{APPENDIX 10.}

CT Rendering of the nepionts and of most of the neanic chambers in specimen A3. Note how each chamber runs through both equatorial planes (see palaeo-electronica.org/content/2016/ 1404-morphology-of-c-carpenteri).

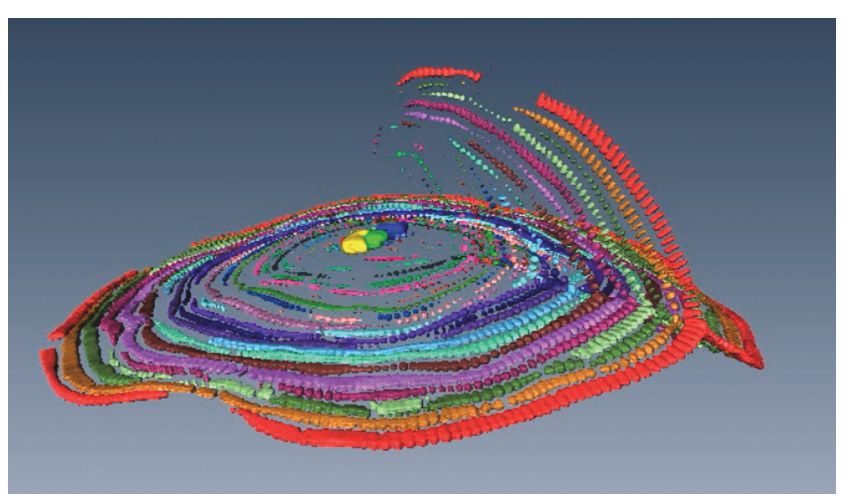

